\title{
Hepatorenal and Testicular Protective Effects of Lycopene against Cadmium Induced Toxicity in Male Rats
}

\author{
Neveen A. Salem ${ }^{1,2^{*}}$ and Emad A. Salem ${ }^{3}$ \\ ${ }^{1}$ Department of Biochemistry, Faculty of Science, AlFaisalia, King Abdulaziz University, Jeddah, Saudi Arabia \\ ${ }^{2}$ Narcotics, Ergogenic Aids and Poisons Department, Medical Research Division, National Research Centre, Giza, Egypt \\ ${ }^{3}$ Department of Urology, Zagazig University, Zagazig, Egypt \\ "Corresponding author: Neveen A Salem, Department of Biochemistry, Faculty of Science, AlFaisalia, King Abdulaziz University, Jeddah, Saudi Arabia, Tel: \\ 202(33335966); Fax: 202(33370931); E-mail: dr_nsalem@yahoo.com
}

Received date: October 26, 2016; Accepted date: October 30, 2016; Published date: October 31, 2016

Copyright: (C) 2016 Salem NA, et al. This is an open-access article distributed under the terms of the Creative Commons Attribution License, which permits unrestricted use, distribution, and reproduction in any medium, provided the original author and source are credited.

\begin{abstract}
Cadmium is a toxic heavy metal in the contaminated environment which accumulates in different organs of the human and animal. Cd exposure leads to the production of reactive oxygen species present study was performed to evaluate the effect of cadmium on the biochemical criteria (ROS). The related to oxidative stress in kidney, liver and testis of adult male rats and to clarify the protective effect of pre and post treatment with lycopene on these criteria. The results showed that cadmium treatment caused significant elevations in liver and kidney weights, serum creatinine, urea, uric acid, aspartate aminotransferse (AST), alanine aminotransferase (ALT), alkaline phosphatase (ALP), gamaglutamyltransferase (GGT), and lactate dehydrogenase (LDH) with significant reductions in weights of testes, epididymis, seminal vesicles and prostate, serum total protein and plasma testosterone. It also markedly increased lipid peroxidation and cadmium concentration in kidney, liver and testis tissues, while significantly decreased superoxide dismutase (SOD), catalase (CAT) activities and reduced glutathione in the tissues of the three organs. Cadmium intoxicated rats showed also considerable increase in the percentages of dead sperms and abnormal sperm rate, while marked decrease in sperm concentration and sperm motility as compared to the control group.
\end{abstract}

Pre-supplementation with lycopene prevented degenerative changes induced by cadmium, reduced oxidative stress and restored the biochemical changes occurring in kidney, liver and testis tissues to near normal group (control). In addition pretreatment with lycopene was more effective than post- treatment in reversing almost all hepatorenal and testicular parameters.

Keywords: Cadmium; Kidney; Liver; Testis functions; Lycopene oxidative stress; Antioxidants

\section{Introduction}

Cadmium (Cd) is dangerous toxic heavy metal in the contaminated environments. It enters to blood kidney, liver and reproductive organs through the ambient air, drinking water, food, industrial materials and consumer products [1]. Ingested cadmium is stored in the renal and sex organs and resulted in renal dysfunction and testicular necrosis [2]. It was suggested that cadmium caused tissue injury in the liver, kidney, testis and other organs by enhancing intra cellular reactive oxygen species (ROS) production and lipid peroxidation which resulted in the release of oxygen free radicals [3]. Cadmium exposure occurs from ingestion of contaminated food or water and can produce long term health effects [4]. Cigarette smoking is also considered to be the most significant source of human cadmium exposure [5].

Recently, lycopene (Lc) has attracted considerable attention as a potential chemo preventive agent. It is an aliphatic hydrocarbon, naturally occurring carotenoid in tomatoes. Lc is highly efficient antioxidant with high free radical scavenging capacity and has singlet oxygen [6]. The salutary effects of lycopene could be attained through different mechanisms including carcinogen metabolism, regulation of intracellular gap-junction communication, gene function regulation, modulation of various metabolic pathway of xenobiotic, hormone and immune modulation [7].

Therefore, the aim of the present study was to evaluate the effect of cadmium on the biochemical criteria related to oxidative stress in liver, kidney and testes of adult male rats and to highlight the protective effect of lycopene on these criteria.

\section{Material and Methods}

\section{Experimental animals}

Sixty adult male albino rats of similar age (10 weeks) and weight $(210 \pm 20 \mathrm{~g})$ were selected for this study. The animals were obtained from the breeding stock of Faculty of Veterinary, Zagaig University, Egypt. They were kept under standard laboratory conditions $\left(25 \pm 2^{\circ} \mathrm{C}\right.$ and $12 \mathrm{~h} / 12 \mathrm{~h}$ light /dark cycle). Rodent chew diet and clean water provided ad libitum. All animal procedures are in accordance with the guidelines of Ethical Committee of the National Institutes of Health Guide for Care and use of Laboratory animals (Publication No 85-23 revised 1996). All rats were acclimatized for two weeks prior to the beginning of the study. 


\section{Chemicals}

Cadmium chloride ( $\mathrm{Cd} \mathrm{Cl}_{2} 99 \%$ pure) was purchased from Sigma Aldrich Chemicals Co. (St. Louis, Mo, USA). Cadmium chloride was dissolved in saline solution $(0.9 \% \mathrm{Na} \mathrm{Cl})$ and injected subcutaneously at a dose of $5 \mathrm{mg} / \mathrm{kg}$ b.w. Lycopene (Natural $15 \mathrm{mg}, 30$ tablets, Leader Pharm-Company) was suspended in corn oil and administered by gavage at a dose of $4 \mathrm{mg} / \mathrm{kgb}$.w. All other chemicals and reagents were of analytical grade and obtained from standard commercial suppliers.

\section{Experimental design}

Two weeks after acclimatization to the laboratory conditions, the animals were randomly classified into 6 groups, ten rats for each:

- Control group: rats were treated with corn oil, orally and injected with saline for two months and served as normal control.

- Lcgroup: rats were administered by gavage with lycopene ( 4 $\mathrm{mg} / \mathrm{kg}$ b.w.) once every other day for two months

- Cd group: rats were injected SC with cadmium ( $5 \mathrm{mg} / \mathrm{kg}$ b.w.) once every other day for two months.

- Lc + Cd group: rats were administered by gavage with lycopene (4 $\mathrm{mg} / \mathrm{kg}$ b.w.) followed after one hour by injection SC with cadmium ( $5 \mathrm{mg} / \mathrm{kg}$ b.w.) once every other day for two months.

- Recovery group: rats were injected SC with cadmium $(5 \mathrm{mg} / \mathrm{kg}$ b.w.) daily for the first month and then left for recovery without any type of administration for another month.

- $\mathrm{Cd}+\mathrm{Lc}$ group: rats were injected SC with cadmium (5 mg/kg b.w.) daily for the first month and then administered by gavage with lycopene ( $4 \mathrm{mg} / \mathrm{kg}$ b.w.) daily for another month.

\section{Blood collection}

After two days from the end of the experiment, all animals were fasted overnight and euthanized and blood samples were collected in the morning via Retro-Orbital bleeding. One portion of blood samples were collected and stored in tubes containing sodium oxalate (2\%) and centrifuged at $3000 \mathrm{pm}$ for 15 minutes using a bench centrifuge. Plasma was separated and stored at $-20^{\circ} \mathrm{C}$ for further determination of testosterone.

The other portion of blood samples were collected in centrifuge tubes for serum separation, centrifuged at $3000 \mathrm{rpm}$ for 15 minutes $\left(4^{\circ} \mathrm{C}\right)$ and stored at $-20^{\circ} \mathrm{C}$ as aliquots for further determinations of creatine, urea, uric acid, aspartate aminotransferase (AST) activity, alanine aminotransferase (ALT) activity, alkaline phosphatase (ALP) activity, gamma glutamyl transferase (GGT) activity, lactate dehydrogenase (LDH) activity, total protein (TP).

\section{Tissue samples}

After blood collection, all rats were rapidly sacrificed and the liver, kidney and testes immediately excised, washed several times from blood by ice-cold isotonic saline, weighed and blotted dry. A known weight of each of liver and kidney were shock-freezed in liquid nitrogen $\left(-170^{\circ} \mathrm{C}\right)$ and stored at $-20^{\circ} \mathrm{C}$ for biochemical analysis. Testes, epididymis, seminal vesicles and ventral prostate were dissected from any adhering connective tissue, weighed and assayed immediately. Plasma and testis samples were stored at $-20^{\circ} \mathrm{C}$ for biochemical analysis. The specimens of each organ (kidney, liver and testis) were homogenized with tissue homogenizer individually to make $10 \%$ of homogenate to assay the tissue oxidants and antioxidants including lipid peroxidation, super oxide dismutase (SOD) activity, and catalase (CAT) activity and reduced glutathione (GSH). The homogenates were prepared for analysis by centrifugation at $18000 \mathrm{rpm}\left(4^{\circ} \mathrm{C}\right)$ for 30 minutes and the supernatant was kept at $-2^{\circ} \mathrm{C}$ for biochemical analysis.

The remaining portions of kidney, liver and testis were kept in hot air oven at $100^{\circ} \mathrm{C}$ for $24 \mathrm{~h}$. The dried sample was transferred to a cool muffle furnace and the temperature was slowly raised to $450^{\circ} \mathrm{C}$ and ached overnight. The ash was used to determine the concentration of cadmium in each tissue.

\section{Biochemical analysis}

Serum analysis: Creatinine and urea as indicators to kidney function were measured spectrophotometrically using standardized commercially available diamond kits Egypt. Uric acid was determined [8], using reagent kits No Ca 2120 obtained from Bio-diagnostic Company Egypt.

Serum AST and ALT activities were determined spectrophotometrically [9]. Alkaline phosphatase (ALP) activity was measured spectrophotometrically at $405 \mathrm{~nm}$ [10].Gammaglutamyltransferase (GGT) activity was measured spectrophotometrically using diagnostic kits [11]. The activity of lactate dehydrogenase (LDH) was determined using colorimetric spectrophotometer [12]. Total protein in serum was colorimetrically determined [13].

Tissue homogenate analysis: The amount of malondialdehyde (MDA) in tissue homogenate of kidney, liver and testes as an index of lipid peroxidation was determined [14] based on the reaction with thiobarbituric acid and was expressed as $\mathrm{nmol} / \mathrm{mg}$ tissue. SOD activity was determined [15] and expressed as $\mathrm{u} / \mathrm{mg}$ tissue. Reduced glutathione (GSH) concentration was assayed [16] and expressed as $\mu \mathrm{mol} / \mathrm{mg}$ tissue. Catalase (CAT) activity was determined [17], based on decomposition of hydrogen peroxide by catalase enzyme .Such decomposition rate is directly proportional to the activity of catalase enzyme and expressed as $\mu / \mathrm{mg}$ protein.

Cd concentration in tissues homogenate was measured by atomic absorption spectrophotometry [18] and expressed as $\mu \mathrm{g} / \mathrm{g}$ tissue.

Epididymis sperm quantity, motility and abnormality rate: Spermatozoa in the epididymis were counted [19], using a haemocytometer and light microscope at $\times 200$ magnification. Sperm motility was evaluated [20], on the basis of visual estimation under light microscope at $\times 400$ magnification. Motility was classified as either motile or non-motile. The percentage of abnormal spermatozoa was determined according to the method described by Atessahin et al. [21]. Slides were stained with India ink and viewed under light microscope at $\times 400$ magnification.

Plasma testosterone levels were determined [22] using enzymelinked immunosorbent assay (ELISA) kits form TECO Diagnostics (Anaheim CA) and expressed as $\mathrm{ng} / \mathrm{ml}$.

\section{Statistical analysis}

The obtained data were expressed as mean \pm SD. Homogenesity of variances for each variable was analysed using the Levene test. The data were statistically analyzed by means of one-way analysis of variance (ANOVA) using SPSS software (SPSS Inc. Chicage, IL). Intergroup comparison was performed by duncan's multiple rank test 
using the $\mathrm{m}$ STAT-c computer program. A difference was considered significant at $\mathrm{P}<0.05$.

\section{Results}

Administration of $\mathrm{CdCl}_{2}$ showed severe signs of illness in the third, fifth and sixth groups compared with the other groups. The mortality rate was $20 \%$ ( 2 rats died out of ten) in each of group 3,5 and 6 . No mortalities were observed in groups 1,2 and 4 .

\section{Organs weights}

It is evident from the data presented in Table 1 that Cd-intoxicated rats showed significant increase in the weights of liver, right and left kidney and marked decrease in the right, left testis, right and left epididymis, seminal vesicles and prostate as compared to the normal control.
Insignificant differences between the second group (Lc treatment alone) and the control group concerning the weights of different organs. However, pre-treatment Cd-intoxicated rats with Lc revealed significant reduction in the weights of kidney and liver, while considerable increase in the weights of testis, epididymis, seminal vehicles and prostate as compared to the third group (Cd treatment alone). Thus, pre-treatment with lycopene brought back the weights of liver, kidney and testes to almost near the control group.

Post treatment with lycopene was less effective than pre- treatment in reversing the weight of the three organs to be near the control group. In the fifth group which administered Cd with the dose of $5 \mathrm{mg} / \mathrm{kg}$ b.w. daily for one month and then left for recovery without any type of administration for another month, it was found partial recovery in the weights of the three organs.

\begin{tabular}{|c|c|c|c|c|c|c|c|c|c|}
\hline \multirow[t]{2}{*}{ Groups } & \multirow{2}{*}{$\begin{array}{l}\text { Liver } \\
\text { (g) }\end{array}$} & \multicolumn{2}{|c|}{ Kidney (g) } & \multicolumn{2}{|l|}{ Testes (g) } & \multicolumn{2}{|c|}{ Epididymis (mg) } & \multirow{2}{*}{$\begin{array}{l}\text { Seminal } \\
\text { Vesicles } \\
(\mathrm{mg})\end{array}$} & \multirow{2}{*}{$\begin{array}{l}\text { Prostate } \\
(\mathrm{mg})\end{array}$} \\
\hline & & Right & Left & Right & Left & Right & Left & & \\
\hline Control & $\begin{array}{l}25.3 \pm{ }^{e} \\
2.1\end{array}$ & $\begin{array}{l}1.82 \pm \mathrm{e} \\
0.21\end{array}$ & $\begin{array}{l}1.80 \pm^{d} \\
0.19\end{array}$ & $\begin{array}{l}1.6 \pm^{a} \\
0.14\end{array}$ & $\begin{array}{l}1.50 \pm^{a} \\
0.14\end{array}$ & $\begin{array}{l}0.46 \pm^{a} \\
0.06\end{array}$ & $\begin{array}{l}0.47 \pm^{a} \\
0.05\end{array}$ & $\begin{array}{l}0.73 \pm^{a} \\
0.06\end{array}$ & $\begin{array}{l}0.35 \pm^{a} \\
0.02\end{array}$ \\
\hline Lc & $\begin{array}{l}25.2 \pm \mathrm{e} \\
3.1\end{array}$ & $\begin{array}{l}1.84 \pm \mathrm{e} \\
0.18\end{array}$ & $\begin{array}{l}1.83 \pm^{d} \\
0.17\end{array}$ & $\begin{array}{l}1.57 \pm^{a} \\
0.12\end{array}$ & $\begin{array}{l}1.55 \pm^{a} \\
0.13\end{array}$ & $\begin{array}{l}0.48 \pm^{a} \\
0.03\end{array}$ & $\begin{array}{l}0.48 \pm^{a} \\
0.04\end{array}$ & $\begin{array}{l}0.72 \pm^{a} \\
0.05\end{array}$ & $\begin{array}{l}0.36 \pm \pm^{a} \\
0.03\end{array}$ \\
\hline $\mathrm{Cd}$ & $\begin{array}{l}55.6 \pm^{a} \\
7.1\end{array}$ & $\begin{array}{l}2.72 \pm^{a} \\
0.24\end{array}$ & $\begin{array}{l}2.70 \pm^{a} \\
0.22\end{array}$ & $\begin{array}{l}1.02 \pm^{d} \\
0.09\end{array}$ & $\begin{array}{l}1.03 \pm^{d} \\
0.08\end{array}$ & $\begin{array}{l}0.30 \pm^{c} \\
0.02\end{array}$ & $\begin{array}{l}0.31 \pm^{c} \\
0.03\end{array}$ & $\begin{array}{l}0.32 \pm^{c} \\
0.04\end{array}$ & $\begin{array}{l}0.17 \pm^{c} \\
0.02\end{array}$ \\
\hline $\mathrm{Lc}+\mathrm{Cd}$ & $\begin{array}{l}27.8 \pm \text { de } \\
2.6\end{array}$ & $\begin{array}{l}1.92 \pm^{d} \\
0.29\end{array}$ & $\begin{array}{l}1.93 \pm^{c} \\
0.27\end{array}$ & $\begin{array}{l}1.48 \pm^{\mathrm{ab}} \\
0.15\end{array}$ & $\begin{array}{l}1.46 \pm a b \\
0.16\end{array}$ & $\begin{array}{l}0.44 \pm \mathrm{ab} \\
0.05\end{array}$ & $\begin{array}{l}0.43 \pm a b \\
0.06\end{array}$ & $\begin{array}{l}0.66 \pm \mathrm{ab} \\
0.05\end{array}$ & $\begin{array}{l}0.30 \pm a b \\
0.03\end{array}$ \\
\hline Recovery & $\begin{array}{l}39.1 \pm \mathrm{b} \\
4.6\end{array}$ & $\begin{array}{l}2.18 \pm b \\
0.22\end{array}$ & $\begin{array}{l}\text { 2. } 16 \pm^{b} \\
0.21\end{array}$ & $\begin{array}{l}1.17 \pm \mathrm{cd} \\
0.09\end{array}$ & $\begin{array}{l}1.16 \pm \mathrm{cd} \\
0.11\end{array}$ & $\begin{array}{l}0.38 \pm b c \\
0.04\end{array}$ & $\begin{array}{l}0.39 \pm b c \\
0.03\end{array}$ & $\begin{array}{l}0.54 \pm b c \\
0.04\end{array}$ & $\begin{array}{l}0.25 \pm b c \\
0.02\end{array}$ \\
\hline$C d+L c$ & $\begin{array}{l}35.4 \pm^{c} \\
4.1\end{array}$ & $\begin{array}{l}2.09 \pm{ }^{b} \\
0.19\end{array}$ & $\begin{array}{l}2.06 \pm b c \\
0.21\end{array}$ & $\begin{array}{l}1.28 \pm b c \\
0.12\end{array}$ & $\begin{array}{l}1.27 \pm b c \\
0.14\end{array}$ & $\begin{array}{l}0.41 \pm b c \\
0.03\end{array}$ & $\begin{array}{l}0.40 \pm{ }^{b} \\
0.04\end{array}$ & $\begin{array}{l}0.58 \pm^{b} \\
0.06\end{array}$ & $\begin{array}{l}0.28 \pm{ }^{b} \\
0.03\end{array}$ \\
\hline
\end{tabular}

Table 1: Effect of pre and post treatment with lycopene (Lc) on liver, kidney, testes weights of cadmium (Cd) intoxicated male rats. Values are expressed as means \pm SE. Means followed by the same alphabetical letter are not significantly different at $\mathrm{p}<0.05$. a: Cd, b: recovery, c: Cd+ Lc, d: control, e: Lc, ab: recovery, bc: Lc+Cd, cd: Cd+ Lc, de: Lc+Cd

\section{Kidney, liver and testis functions}

There was no significant difference in the functions of kidney, liver and testes between the second group (Lc treatment alone) and the control group (Figure 1) The treatment of male rats with Cd caused significant elevations in the levels of creatinine (140\%) urea (91\%), uric acid (98\%) as compared to the control group, reflecting kidney function and renal structural integrity. Pre-treatment with Lc markedly enhanced the renal indices reaching almost near the normal control group. Post-treatment with Lc was less effective than pre-treatment in reversing the levels of renal indices.

Exposure of the experimental animals to Cd was accompanied by considerable increase in hepatic indices, i.e. AST, ALT, ALP, GGT and LHD and marked decrease in serum total protein (TP) as compared to the normal control group. However, Co-administration of Lc prior to Cd-treated rats showed results approximating those in the control group with respect to hepatic indices. Post-treatment with Lc was less effective than pre-treatment in reversing the levels of hepatic indices followed by the fifth group which administered $5 \mathrm{mg} / \mathrm{kg}$ b.w. cadmium daily for one month and then left for recovery without any type of administration for another month in which partial recovery of hepatic indices was observed.

Cd-intoxicated rats showed significant decrease (-59\%) in the level of plasma testosterone as compared to the control group. However, pre-treatment $\mathrm{Cd}$ - intoxicated rats with Lc significantly enhanced the level of plasma testosterone as compared to $\mathrm{Cd}$ group and brought back the level of testosterone to almost near the control group. Pretreatment with Lc was more effective than post-treatment in reversing the values of testicular index. Partial recovery of plasma testosterone was also detected in the fifth group (Figure 1). 

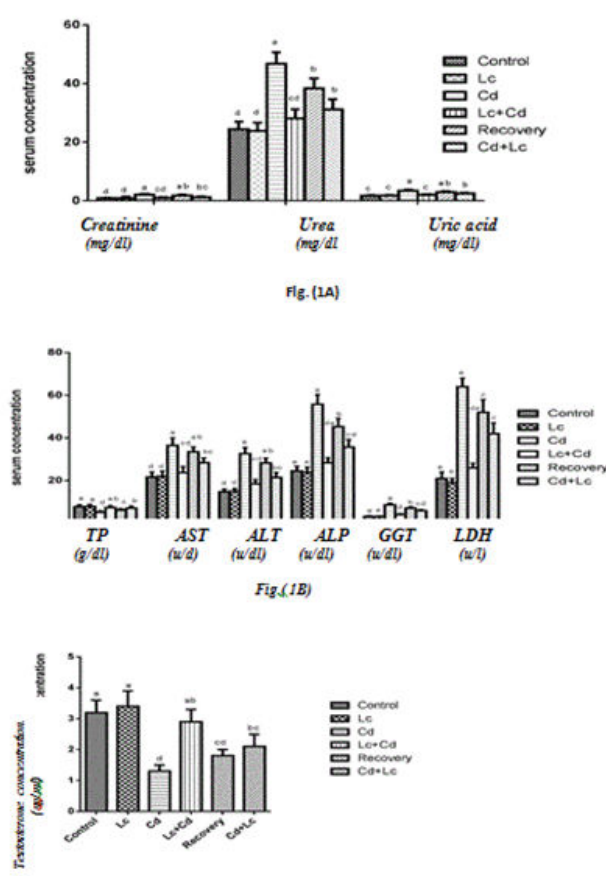

Figure 1: Effect of pre and post treatment with lycopene $(\mathrm{Lc})$ on renal (1A), hepatic (1B) and testicular (1C) parameters in serum and plasma of cadmium $(\mathrm{Cd})$ intoxicated male rats. Values are expressed as means \pm SE. Columns followed by the same alphabetical letter are not significantly different at $\mathrm{p}<0.05$.

\section{nd Cd concentration in tissues}

The data illustrated in Figure 2 revealed that exposure the rats to Cd resulted in an increase of 35\%,58\% and 54\% in the amount of MDA in kidney, liver and testis tissues, respectively as compared to the control group. The concentration of cadmium was significantly increased in the tissues of kidney liver and testis of Cd-intoxicated rats when compared to the control group. However, the level of GSH and the activities of SOD and CAT were markedly decreased in the tissues of the three organs of $\mathrm{Cd}$ intoxicated rats as compared to the control group (Figure 3). Pre-treatment with Lc brought back the concentration of $\mathrm{Cd}$, the levels of MDA and GSH as well as the activities of SOD and CAT to near the normal control group. It is evident that there was insignificant difference between pre-treatment Cd-intoxicated rats with Lc and the control group concerning the levels, of MDA, GSH and SOD in the three organs tissues, indicating clearly the therapeutic value of Lc. Post-treatment Cd- intoxicated rats with Lc was less effective than pre-treatment in reversing the functions of kidney, liver and testis to the normal control.

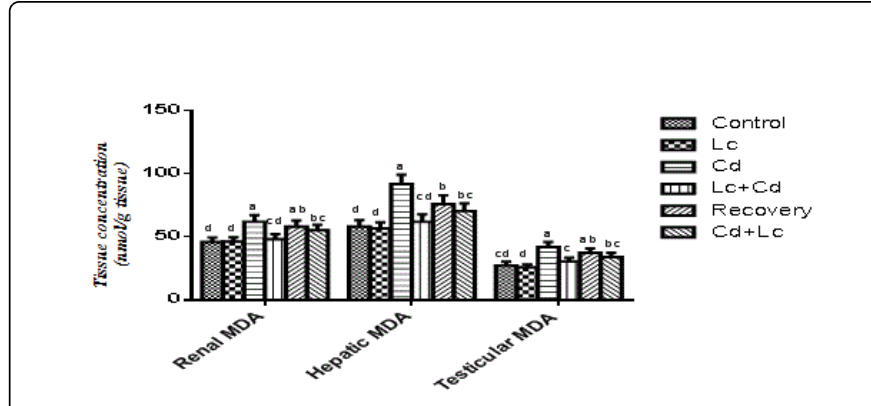

Figure 2: Effect of Pre and Post treatment with lycopene on Malondialdehyde and in kidney (A), liver (B) and testes (C) tissues of cadmium (Cd) intoxicated male rats Values are expressed as means \pm SE. Columns followed by the same alphabetical letter are not significantly different at $\mathrm{p}<0.05$.

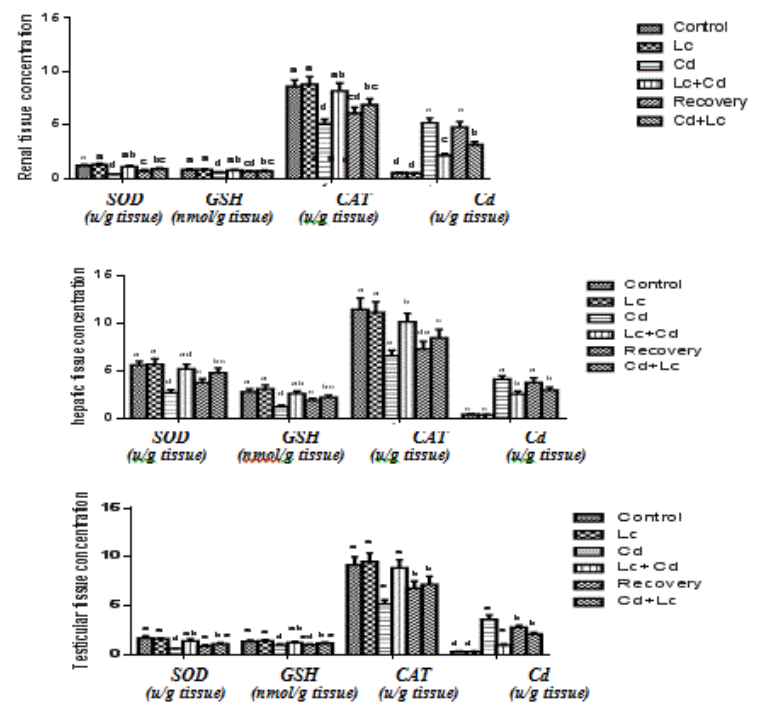

Figure 3: Effect of Pre and Post treatment with lycopene on some antioxidants and cadmium content in kidney (A), liver (B) and testes $(\mathrm{C})$ tissues of cadmium $(\mathrm{Cd})$ intoxicated male rats Values are expressed as means \pm SE. Columns followed by the same alphabetical letter are not significantly different at $\mathrm{p}<0.05$.

\section{Sperm characteristics}

As shown in Table 2 there was no significant difference in sperm characteristics between the first group (control) and the second group (Lc treatment alone). However Cd intoxicated rats showed significant reduction in the sperm concentration (53\%) and motility (52\%), while significant increase in the percentages of dead sperm (158\%) and abnormal sperm rate (148\%) as compared to the normal control. On the other hand, pre-treatment Cd-intoxicated rats with Lc brought back sperm characteristics to approximately near the normal control, indicating the beneficial effect of Lc on sperm characteristics. Post treatment $\mathrm{Cd}$ intoxicated rats with Lc was less effective than pretreatment in reversing the values of sperm characteristics to the normal control. 


\begin{tabular}{|l|l|l|l|l|}
\hline Groups & $\begin{array}{l}\text { Sperm } \\
\text { concentration } \\
\text { million/g }\end{array}$ & $\begin{array}{l}\text { Sperm } \\
\text { motility } \\
\%\end{array}$ & $\begin{array}{l}\text { Dead } \\
\text { sperm } \\
\%\end{array}$ & $\begin{array}{l}\text { Abnormal } \\
\text { sperm rate } \\
\%\end{array}$ \\
\hline Control & $268.0 \pm 14.1^{\mathrm{a}}$ & $74.9 \pm 5.2^{\mathrm{ab}}$ & $16.5 \pm 1.2^{\mathrm{de}}$ & $8.6 \pm 0.90^{\mathrm{c}}$ \\
\hline LC & $280.4 \pm 16.2^{\mathrm{a}}$ & $77.9 \pm 6.3^{\mathrm{a}}$ & $14.9 \pm 1.4^{\mathrm{e}}$ & $7.2 \pm 0.82^{\mathrm{c}}$ \\
\hline Cd & $125.8 \pm 11.5^{\mathrm{e}}$ & $36.1 \pm 2.8^{\mathrm{e}}$ & $42.6 \pm 3.5^{\mathrm{a}}$ & $21.3 \pm 1.09^{\mathrm{a}}$ \\
\hline LC + Cd & $242.2 \pm 9.2^{\mathrm{bc}}$ & $65.2 \pm 5.6^{\mathrm{bc}}$ & $20.8 \pm 1.7^{\mathrm{cd}}$ & $14.0 \pm 0.92^{\mathrm{b}}$ \\
\hline Recovery & $212.3 \pm 18.4^{\mathrm{d}}$ & $55.1 \pm 6.2^{\mathrm{d}}$ & $35.2 \pm 2.9^{\mathrm{b}}$ & $16.4 \pm 1.2^{\mathrm{b}}$ \\
\hline Cd + LC & $235.6 \pm 19.6^{\mathrm{c}}$ & $59.0 \pm 4.8^{\mathrm{cd}}$ & $28.7 \pm 2.2^{\mathrm{b}}$ & $14.3 \pm 1.1^{\mathrm{b}}$ \\
\hline
\end{tabular}

Table 2: Effect of pre and post treatment with lycopene (Lc) on sperm characteristics of cadmium $(\mathrm{Cd})$ intoxicated male rats. Values are expressed as means \pm SE. Means followed by the same alphabetical letter are not significantly different at $\mathrm{p}<0.05$. $\mathrm{a}: \mathrm{Cd}, \mathrm{b}$ : recovery, $\mathrm{c}$ : $\mathrm{Cd}+$ Lc, d: control, e: Lc, ab: recovery, bc: Lc+Cd, cd: Cd+ Lc, de: Lc+Cd

\section{Discussion}

Cadmium is considered one of the most toxic metals that may induce oxidative damage by disturbing the prooxidant-antioxidant balance in the tissues. Liver, Kidney and testes are the target organs following $\mathrm{Cd}$ exposure with the severity of their intoxication. The mechanism of tissue damage induced by cadmium includes the production of free radicals that alter mitochondrial activity and genetic information [23].

The present study concentrates on the possible protective effect of pre or post-treatment with lycopene on oxidative damage generated by cadmium induced hepatorenal and testicular toxicity. Cadmium intoxicated rats showed significant increase in the weights of liver, right and left kidney as compared to the untreated rats (control). These results may be due to the hypertrophy induced in both liver and kidney as a result of cadmium toxicity which is attributed with hyperemia, sinusoid dilation and increased kapffer cells in the liver and dilation of renal glomeruli in the kidney [24]. These findings are in agreement with previous reports demonstrating that $\mathrm{Cd}$ toxicity leads to abnormal body and organs weights in rats [25].

Otherwise, cadmium intoxicated rats produced lighter weights of both right and left testis, right and left epididymis, seminal vesicles and prostate. These results are in accordance with the finding of Elgawish and Ghanem [26] who reported that the weights of testis, epididymis, seminal vesicles and prostate glands were decreased in rats received $\mathrm{Cd}$ as compared to the control. The reduction in the weights of testes and epididymis due to cadmium administration may be attributed with the inhibition of spermatogenesis, decreased elongated spermatids and steroidogenic enzyme activity [27].

Serum protein level is a measure of overall liver function. According to the present study Cd-intoxicated rat's revealed significant decrease of serum total protein. These results are supported by the finding of Hassan et al. [28]. The liver is known to play an essential role in synthesis of serum protein. Also kuffer cells of the liver are known for antigenicity as they phagocytosis antigen. The toxicity of $\mathrm{Cd}$ may involve a reaction of reactive oxygen species (ROS) as described by Manca et al. [29]. In addition Cd damage is typically located in the proximal tubule and it decreases proteins reabsorption [30]. The

reduction of serum protein in rats exposed to $\mathrm{Cd}$ is supported by the finding of Babaknejad et al. [31].

The results obtained in the present study showed that pre and posttreatment with Lc prevented the toxic effect of $\mathrm{Cd}$ and produced significant elevations of serum protein as compared to Cd group. However the effect of pre-treatment with Lc was more prominent than that of post-treatment. The possible explanation for the protective effect of lycopene against $\mathrm{Cd}$-induced lipid peroxidation and hepatoxicity is its ability to react with the oxygen metabolites [32].

In the current study pre or post-administration of $\mathrm{Lc}$ and $\mathrm{Cd}$ produced a significant decrease in the weights of liver and kidney compared with the Cd group. However the effect of pre-treatment with Lc was more prominent than that of post treatment. It is interest to mention that lycopene pre-treatment in Cd-administered rats showed approximately normal liver, kidney and testis weights. The chemopreventive effect of Lc might be due to its highly efficient antioxidant with high free radical scavenging capacity and has singlet oxygen [6]. Lc has a salutary effect on regulation of intracellular gapjunction communication, gene function regulation, modulation of various metabolic pathway of xenobiotic, hormone and immune modulation [7].

The results of the present study indicated that $\mathrm{Cd}$ administration at the dose of $5 \mathrm{mg} / \mathrm{kg}$ b.w resulted in a significant increase of serum creatinine, urea and uric acid, indicating the impairment in the kidney function. These increases reached $42 \%$ for creatinine, $87 \%$ for urea and $98 \%$ for uric acid as compared to the control group. In this connection, urea and creatinine levels are used to monitor renal function and their levels will not rise until at least $50-70 \%$ of the kidney nephrons are destroyed [33]. Treatment with Lc brought back the concentration of creatinine, urea and uric acid to almost near their normal concentrations, indicating clearly the therapeutic value of Lc. In this connection, Sharma and Vijaya [34] reported that lycopene, treatment prevented degenerative changes induced by $\mathrm{Cd} \mathrm{Cl}_{2}$ which confirmed the results obtained in the current study.

It is interest to mention that pre-treatment with Lc was more effective than post-treatment in reversing almost all renal parameters, ie. creatinine, urea and uric acid in cadmium intoxicated rats to be near or close to their level in control group.These results are in the same line with that of Dakrory et al. [35].

In the fifth group and at the end of two months, the data showed partial recovery of the toxic effect of cadmium administration with the dose of $5 \mathrm{mg} / \mathrm{kg}$ b.w. daily for the first month concerning the weights of liver kidney and testis as well as the concentrations of serum creatinine, urea and uric acid, indicating that the adverse effect induced by $\mathrm{Cd}$ administration are reversible. The obtained results may be attributed with bioenergetic recovery [36].

The present results showed that intoxicated rats with cadmium significantly elevated AST, ALT, ALP, GGT and LDH as compared to the control group. The elevation in serum activities of AST, ALT, ALP, GGT and LDH in Cd intoxicated rats had been attributed to the damage structural integrity of liver, because these markers are normally located in the cytoplasm, mitochondria or microsomes and are released into circulation after cellular damage [37]. This also may be due to increasing cell membrane permeability or cell membrane damage of hepatocytes under the influence of cadmium. The increase of serum GGT is the testimony of the ubiquity of hepatoxicity and oxidative damage in liver cells $[38,39]$. In addition, ALP is considered as an enzyme of hepatocytes plasma membrane. Thus an increase in 
serum ALP activity has been related to damage of the liver cell membrane (40).

Co-administration of LC with cadmium significantly reduced the levels of liver enzymes activity, i.e. AST, ALT, ALP, GGT and LDH as compared with the Cd-group. Pretreatment $\mathrm{Cd}$-intoxicated rats with Lc brought back the levels of AST, ALT, ALP, GGT and LDH activities to near normal group, indicating the protective effect of lycopene in ameliorating the hepatoxic effect of $\mathrm{Cd}$. These results are in accordance with the finding of Tokak et al. [39]. However post treatment with Lc was less effective than pre-treatment in attenuating ALT, AST, ALP, GGT and LDH as biochemical markers of hepatocellular damage.

Partial recovery was detected in the levels of liver enzymes activity of the fifth group which administered Cd with the dose of $5 \mathrm{mg} / \mathrm{kg}$ b.w. daily for one month and then left for recovery without any type of administration for another month, indicating the reversibility of adverse effect induced by cadmium.

The plasma testosterone level is considered to be a useful indicator of testicular function [40,41]. Testosterone is the main secretory product of testis and acts as both an endocrine and local factor within the testis [42]. The obtained data in the present study revealed a significant decrease in the level of testosterone in Cd-intoxicated rats. In this connection, similar findings were reported $[43,44]$. These results could be attributed to the leyding cell dysfunction and decreased number of luteinizing hormone (LH) receptors on leading cells lending to steroidogenic disorder [45]. However pretreatment Cdintoxicated rats with Lc brought back the level of testosterone to almost close to control group. In addition post-treatment with Lc increased significantly testosterone level compared to Cd group. Lc treatment enhanced the level of testosterone. The therapeutic effect of lycopene obtained in the current study is supported by the finding of Salem et al. [46], who reported that Lc significantly enhanced the level of plasma testosterone in male rats.

The results of the present study indicated that $\mathrm{Cd}$ administration at the dose $5 \mathrm{mg} / \mathrm{kg}$ b.w. leads to a significantly increased accumulation of cadmium in the kidney, liver, testis tissues of rats treated with $\mathrm{Cd}$. These results are in accordance with the findings of Gaurav et al. [33] and Mafulul and Okoye [47], who showed that intake of cadmium, induces its accumulation in these tissues and alters the enzymatic and non-enzymatic components of antioxidant defense system. However, pre-treatment with Lc prior Cd administration significantly lowered the concentrations of $\mathrm{Cd}$ in the kidney, liver and testis tissues of rats treated with $\mathrm{Cd}$. In addition post-treatment with $\mathrm{Lc}$ after $\mathrm{Cd}$ administration significantly attenuated the levels of $\mathrm{Cd}$ in the studied tissues. However, pre-treatment with Lc was more effective than posttreatment. The decreased level of $\mathrm{Cd}$ in the kidney, liver and testis tissues after pre or post-treatment with Lc could be explained on the basis of formation cadmium lycopene complexes or cadmiummetallothione in complexes [48].

Cadmium intoxicated rats showed significant increase in MDA of the different organs tissues studied as compared to the normal control group. Otherwise, the level of SOD, GSH and CAT in the studied tissues was significantly decreased following exposure to cadmium similar findings were also reported earlier $[31,47,48]$. It was found that pre as well as post treatment Cd-intoxicted rats with Lc effectively decreased the accumulation of $\mathrm{Cd}$ in kidney, liver and testis tissues and induction of MDA, whereas significantly increased the levels of SOD, GSH and CAT in the studied tissues.
MDA is an end product of lipid peroxidation. It is a major early manifestation of oxidative damage of organs tissues and plays an important role in the induction of toxic lesions by Cd [47]. GSH plays a critical role in drug detoxification reactions, breakdown of intracellular peroxides or free radicals and plays a major role in the maintenance of mitochondrial rfunction . Administration of Lc helps to overcome the oxidative stress by increasing GSH levels [32].

The antioxidant enzymes SOD and CAT in kidney, liver and testis tissues were decreased in Cd-intoxicated rats.SOD accelerates the conversion of superoxide radical $\left(\mathrm{O}^{2-}\right)$ to hydrogen peroxide, while CAT is an inducible cytosolic enzyme, which serves to protect the biological system against reactive oxygen species, converting hydrogen peroxide to non-toxic oxygen and water [34]. The significant increases of these enzymes in the tissues were provided with Lc treatment, providing evidence that Lc might have a significant activity in maintaining antioxidant enzymes. These results are in accord with previous findings $[39,46,49]$, indicating, the useful effects of Lc in preventing hepatorenal and testicular damage induced by $\mathrm{Cd}$ exposure.

It has been found that $\mathrm{Cd}$ leads to a significant decrease in epididymal sperm concentration, motility and significant increase in the percentage of dead sperms and abnormal sperm morphology rate in comparison with the control group. In this connection similar findings were previously reported $[3,26,49]$.

The diminution of epididyal sperm concentration, motility and normal sperm morphology rate in Cd intoxicated rats may be caused by lipid peroxidation of unsaturated fatty acids in the sperm plasma membrane, resulting in a loss of its fluidity and function [46].

Pre or post-treatment with Lc to the Cd-intoxicated rats resulted in attenuation the adverse effect of $\mathrm{Cd}$ on sperm characteristics and the values were approximately near to the control group. These results correlate with previous findings [46,49] and could be attributed with the antioxidant properties of lycopene.

\section{Conclusion}

The findings of the current study reinforce the significant role of reactive oxygen species in the pathogenesis of $\mathrm{Cd}$-induced oxidative damage in the rat kidney, liver and testes tissues. Pre-treatment Cdintoxicated rats with Lc could be effective for prophylaxis of $\mathrm{Cd}$ induced hepatorenal and testicular injury for its potent cytoprotective effects against the deleterious toxic effects caused by Cd. Lycopene showed marked protective affects against cadmium induced toxicity in rats. Further studies are required to recommend the use of Lc and its therapeutic potential in human.

\section{References}

1. Nordberg GF, Fowler BA, Nordberg M, Friberg LT (2011) Cadmium. In handbook on the toxicology of metals (3rd edn). Academic Press: Burlington MA. USA.

2. May TW, McKinney GL (1981) Cadmium, lead, mercury, arsenic, and selenium concentrations in freshwater fish, 1976-77--National Pesticide Monitoring Program. Pestic Monit J 15: 14-38.

3. Lafuente A, Cano P, Esquifino A (2003) Are cadmium effects on plasma gonadotropins, prolactin, ACTH, GH and TSH levels, dose-dependent? Biometals 16: 243-250.

4. Bernhoft, R.A. (2013): Cadmium toxicity and treatment. The scientific world Journal. Hindawi publishing Corporation.

5. Friberg L (1983) Cadmium. Annu Rev Public Health 4: 367-373. 
6. Cohen LA (2002) A review of animal model studies of tomato carotenoids, lycopene, and cancer chemoprevention. Exp Biol Med (Maywood) 227: 864-868.

7. Heber D (2006) Mechanism of action of lycopene. In: Rao V, teil A (eds). Tomatoes, lycopene and human Health, Scotland: Caledonian Science Press.

8. Barham D, Trinder P (1972) An improved colour reagent for the determination of blood glucose by the oxidase system. Analyst 97: 142-145.

9. Reitman S, Frankel S (1957) A colorimetric method for the determination of serum glutamic oxalacetic and glutamic pyruvic transaminases. Am J Clin Pathol 28: 56-63.

10. Belfield A, Goldberg DM (1997) Revised assay for serum phenyl phosphatase activity using 4-amino-antipyrine. Enzyme 12: 561-573.

11. Szasz G (1969) A kinetic photometric method for serum gammaglutamyl transpeptidase. Clin Chem 15: 124-136.

12. Baba C, Yanagida K, Kanzaki T and Babe M (2005) Colorimetric lactate dehydrogenase (LDH) assay for evaluation of antiviral activity against bovine viral diarrhoea virus (BVDV) invitro. Antiviral chemistry and Chemotherapy 16: 33-39.

13. Chromy V, Fischer J (1977) Photometric determination of total protein in lipemic sera. Clin Chem 23: 754-756.

14. Ohkawa H, Ohishi N, Yagi K (1979) Assay for lipid peroxides in animal tissues by thiobarbituric acid reaction. Anal Biochem 95: 351-358.

15. Sun Y, Oberley LW, Li Y (1988) A simple method for clinical assay of superoxide dismutase. Clin Chem 34: 497-500.

16. Ellman GL (1959) Tissue sulfhydryl groups. Arch Biochem Biophys 82: 70-77.

17. Clairborne A (1985) Catalase activity. In: Greenwald RA (eds). Handbook of Methods for Oxygen Radical Research. Boca, Ration, Florida CRC Press: 283-284.

18. Shirley RL, Beune WJ, Miller MJ (1949) Cadmium in biological materials and food Anal Chem 21:300-303.

19. Yokoi K, Uthus EO, Nielsen FH (2003) Nickel deficiency diminishes sperm quantity and movement in rats. Biol Trace Elem Res 93: 141-154.

20. Sönmez M, Türk G, Yüce A (2005) The effect of ascorbic acid supplementation on sperm quality, lipid peroxidation and testosterone levels of male Wistar rats. Theriogenology 63: 2063-2072.

21. Atessahin A, Karahan I, Turk G, Gur S, Yilmaz S, et al. (2006) Protective role of lycopene on cisplatin induced changes in sperm characteristics , testicular damage and oxidative stress in rats. Reprod Toxical 21: 42-47.

22. Mourão CA Jr, Schmidt SL, Manhães AC (2003) Testosterone and free thyroxin blood in congenitally acallosal male BALB/cCF mice. Neuro Endocrinol Lett 24: 459-462.

23. De Burbure C, Buchet JB, Leroyer A, Nisse C, Haquenoer JM, et al. (2006) Renal and neurologic effects of cadmium, lead, mercury and arsenic in chilolren: Evidence of early effects and multiple interactions at environmental exposure levels. Environ Health Perspect 114: 584-590.

24. Omid K, Saeed H, Seyyed PM (2014) Toxic effects of cadmium in Japanese quoil (Coturnixjaponica): Assessment of body weight and histopathology of liver and kidneys. Advances in environmental biology 8: 288-294.

25. Flora SJS (2007) Role of free radicals and antioxidants in health and disease. Cell Mol Biol (Noisy-le-grand) 53: 1-2.

26. Elgawish RAR, Ghanem ME (2014) Effect of long term cadmium chloride exposure on testicular function in male albinorats. American Journal of Animal and Veterinary Sciences 9: 182-188.

27. Takahashi O, Oishi S (2003) Testicular toxicity of dietarily or parenterally administered bisphenol $\mathrm{A}$ in rats and mice. Food Chem Toxicol 41: 1035-1044.

28. Hassan RA, Amin DM, Rahmy NA, Hatem ME, Dessouky MI (2012) Clinicopathological, histopathological and immunological studies on animals exposed to lead and cadmium under experimental conditions. New York Science Journal 5:120-136.

29. Manca D, Ricard AC, Trottier B, Cheralier G ( 1991) Studies on lipid peroxidation in rat tissues following administration of low and moderate doses of cadmium chloride. Toxicol 67: 303-323.

30. Aughey E, Fell GS, Scott R, Black M (1984) Histopathology of early effects of oral cadmium in the rat kidney. Environ Health Perspect 54: 153-161.

31. Babaknejad N, Moshtaghie AA, Nayeri H, Shahanipour K, Bahrani S (2016) The protective role zinc and magnesium in cadmium induced renal toxicity in male wistar rats. Biol Trace Elem Res 174:112-120.

32. Ateşşahin A, Türk G, Karahan I, Yilmaz S, Ceribaşi AO, et al. (2006) Lycopene prevents adriamycin-induced testicular toxicity in rats. Fertil Steril 85 Suppl 1: 1216-1222.

33. Gaurav D, Preet S, Dua KK (2010) Protective effect of Spirulinaplatensis on cadmium induced renal toxicity in wistar rats. Arch Appl Sci Res 2: 390-397.

34. Sharma V, Paliwal R (2013) Potential Chemoprevention of 7,12Dimethylbenz[a]anthracene Induced Renal Carcinogenesis by Moringa oleifera Pods and Its Isolated Saponin. Ind J Clin Biochem 29: 202-209.

35. Dakrory AI, Al-Harbi MS, Mohamed AS (2015) Antioxidant role of holothuriaatra extract against nephrotoxicity induced by 7,12 - dimethyl benz (a) anthracenein male albino rats. Int J Adv Res 3: 275-287.

36. Seme MT, Summerfelt P, Neilz J, Eells JT, Henry MM (2001) Differential recovery of retinal function after mitochondrial inhibition by methanol intoxication. Invest Ophthalmol Vis Sci 42: 834-841.

37. Sallie R, Tredger JM, Williams R (1991) Drugs and the liver. Part 1: Testing liver function. Biopharm Drug Dispos 12: 251-259.

38. Tatjana J, Gordana K, Dusica P, Ivana S (2003) Effect of captopril on membrane associated enzymes in lead induced hepatoxicity in rats. Acta Facultatis Medicae Naissensis 20: 183-188.

39. Tokaç M, Aydin S, Taner G, Özkardeș AB, Yavuz Taşlipinar M, et al. (2015) Hepatoprotective and antioxidant effects of lycopene in acute cholestasis. Turk J Med Sci 45: 857-864.

40. Kaplan MM (1986) Serum alkaline phosphatase--another piece is added to the puzzle. Hepatology 6: 526-528.

41. Nair SVG, Rajamoban T (2014) The role of coconut water on nicotineinduced reproductive dysfunction in experimental male rat model. Food and Nutrition Sciences 5: 1121-1130.

42. Weinbauer GF, Luetjens CM, Simoni M, Nieschlag E (2010) Physiology of testicular function. Andrology 17: 11-59.

43. Kamel MM, Abd El Razek AH, Ahmed KA, Kamel GM (2011) Exposure of adult male rats to cadmium: assessment of sexual behavior, fertility, aggression as well as anxiety like behavior with special reference to biochemical and pathological alterations. Life Sci J 8: 106-119.

44. Alhazza IM (2005) Effect of selenium on cadmium induced gonadotoxicity in male rats. J Boil Sci 5: 243-249.

45. Mains MD, Sluss PM, Iscan CP (1990) cis-Platinum-Mediated decrease in serum testosterone is associated with depression of luteinizing hormone receptors and cytohormone P-450SCC in rat testis. Endocrinology 126: 2398-2406.

46. Salem EA, Salem NA, Maarouf AM, Serefoglu EC, Hellstrom WJG (2012) Selenium and lycopene attenuate cisplatin-induced testicular toxicity associated with oxidative stress in wistar rats. Urology 79: 1184 e1-1184 e6.

47. Mafulul SG, Okoye ZSC (2012) Protective effect with presupplementation with selenium on cadmium induced oxidative damage to some rat tissues. Int J Boil Chem Sci 6: 1128-1138.

48. El-Sokkary GH, Nafady AA, Shabash EH (2009) Melatonin ameliorates cadmium-induced oxidative damage and morphological changes in the kidney of rat. The Open Neuroendocrinology Journal 2: 1-9.

49. Sharma S, Vijaya P (2015) Ameliorating potential of lycopene against cadmium toxicity in kidney of albino mice. Int J Adv Res 3: 766-771. 